\title{
The Claims of Diversity: The Uniting Reformed Church, Diversity and Qualitative Unity
}

\author{
Pieter J. Grove \\ https://orcid.org/0000-0002-4868-8612 \\ Uniting Reformed Church in Southern Africa \\ pjgrove1@gmail.com
}

\section{Abstract}

The first 25 years of the Uniting Reformed Church in Southern Africa was dedicated to stabilise and deepen the unity achieved between the former Dutch Reformed Church in Africa and the Dutch Reformed Mission Church, while simultaneously fighting off challenges posed by the break-away DRCA. A vital characteristic of these two churches was that they brought multiple diversities to the unification process - diversities of language, gender, laity, age, spirituality, and different abilities. URCSA did not often address these challenges openly, but they functioned as underground currents that reached visible manifestations when leaders had to be elected. At the last regional synod of URCSA in the Cape (2018), a debate ensued and a contesting of leadership positions occurred, that affirmed a mechanistic model of cultural representation and side-lined greater gender recognition. These attempts bear witness to the reality of diversity and compel URCSA to address this vital issue in a way that remains true to the Gospel, affirming our fundamental unity while drawing on our diversity as sources of enrichment. URCSA has the inestimable resource of the Belhar Confession 1986 that drew on the biblical tradition to approach the issue of diversity and unity. This essay will clarify the issue of diversity in relation to unity in the church and investigate how diversities are addressed as they impact on culture and gender. The author will draw on the work of the late political philosopher, Iris Marion Young, to investigate various approaches to diversity. The essay proposes that if we do not address the reality of diversity in a significant way, the unity of the church will not reach meaningful depth and a new dominating hegemony will replace the aspiration to qualitative unity, thereby limiting the contribution and access of different constituencies in URCSA.

Keywords: Uniting Reformed Church in Southern Africa; Dutch Reformed Church; diversity; unity; politics of difference; Iris Marion Young; Belhar Confession

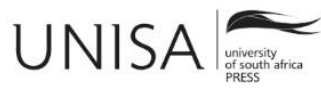




\section{The Reign of Diversity: Apartheid Theology}

At the heart of the old apartheid order was an ideological and theological attempt to elevate the status of diversity to the final measure of how both church and society should be patterned. Although the different churches within the Reformed church family in South Africa shared the same polity, confessions, liturgical tradition, hymns, and so forth, the theology of the Dutch Reformed Church (DRC) and of the apartheid rulers insisted that the different churches remain separate. Separation was the form of institutional church and social formation, but a type of diversity was its rationale. Apartheid, or separate development, was an intensification and hardening of the old segregationist policies of the English colonialists. Prof. C. Villa-Vicencio would argue that the apartheid heresy was pervasive and not limited to the Afrikaner churches: "In spite of the declarations of principle and belief ... separate worship, segregated holy communion services and racially constituted fellowship and service organisations ... are also the hallmarks of all English-speaking churches in this country" (Villa-Vicencio 1983, in De Gruchy and Villa-Vicencio 1983, 67). The scandal of this policy for the churches was that the Afrikaner churches and their state apparatus claimed that they wanted to serve the Gospel vision of unity amongst Christians. The DRC and its white "sister" churches, therefore, segregated the worship service, the sacraments, the polity, the preaching and catechism, while all along claiming to serve the reign of Christ that accomplished the reconciliation of God and humankind. Prof. Johann Kinghorn captured the relationship between the Afrikaner churches and apartheid in his insightful essay, "Modernization and Apartheid: The Afrikaner Churches" (Kinghorn 1997, in Elphick and Davenport 1997, 135-154).

The significant report of the Study Project on Christianity in Apartheid Society (SPROCAS) of 1972, faulted both the Afrikaner churches and the English-speaking churches for grossly distorting the concepts of unity and diversity. According to the report, the English-speaking whites assumed that unity "necessarily involves uniformity" (SPROCAS in Randall 1972, 48-49). This contributed to the exodus of many black Christians from these churches to establish the African Independent Churches. The maintenance of one cultural ethos as exclusively normative enabled the white Christians to retain power of leadership and resources.

The Afrikaner churches, on the other hand assumed that diversity necessarily encouraged division. Dr F. J. M. Potgieter, head of Dogmatics at Stellenbosch Nederduits Gereformeerde Kerk Kweekskool, saw in veelvormige ontwikkeling die wil van God ("diverse development, the will of God"); "Potgieter concluded against "the Liberalists' that Scripture 'quite clearly' opposes integration between whites and blacks and that God is therefore also against a united or integrated Church" (Randall 1972, 49).

The SPROCAS Report (1972) pushed towards a radical conclusion, judging the approaches of both the Afrikaners and the English speakers to be in deep error, but from different sides: "[W]e can suggest that from a Scriptural point of view the Englishspeaking and Afrikaner ideas of the relationship between unity/disunity and 
uniformity/diversity are basically the same mistake from opposite ends. Both assume that unity involves uniformity to some extent and that diversity excludes, or at least imperils, unity" (Randall 1972, 50).

The missiologist, Prof. David Bosch, warned already in 1983 that a church cannot ascribe soteriological significance to cultural distinctiveness (Bosch 1983, in De Gruchy and Villa-Vicencio 1983, 34). However, this was exactly the tendency he observed in the DRC symposium of 1978 on Veelvormigheid en Eenheid ("Diversity and Unity"). The DRC, its white sister churches and the apartheid establishment, did not slide unknowingly into a heretical position on church formation. They constructed that position with a false reading of the biblical witness.

The consequences of a distorted use and absolutisation of diversity were that most black Christians resisted any sustained reflection on the place of diversities in church and theology. Most black churches and Christians wanted to deepen their unity and celebrate their togetherness. The demands of both Gospel, and the struggle against racial and capitalist oppression, required that the quest for unity be primary and this dynamic submerged the rich diversities of the churches. There was clearly a double dynamic operating during the struggle against apartheid. On the one hand the historic context created the momentum for unity, while this simultaneously lined up with the Gospel understanding of the unity of the Church of Christ.

The English-speaking mainstream churches tend to proclaim and protect their own fragile unity. Any cursory study of their realities, however, will disclose that they are grappling with submerged diversities that are often not openly acknowledged. The black churches, like URCSA, were physically segregated, so that the need for unity became overriding and the real issues of diversity did not intrude on theological consciousness or were deliberately suppressed.

On the other hand, there are both black and white churches that continue their segregated paths in the conviction that this is the most fruitful way to serve God and their culture in the current context. In these churches the cultural factor presumably dominates and perhaps serves the identity needs of the applicable communities. However, the presence of various diversities cannot be denied - even in those hegemonic contexts.

\section{The Struggle for Unity: URCSA's Quest}

The missiologist, Prof. Willem Saayman, endeavours to give an overview of URCSA's decisions on unity since 1994 (Saayman 2017, in Plaatjies-Van Huffel and Modise 2017). He observes that from 1881 when the Dutch Reformed Mission Church (DRMC) was established by the NGK for all the members of colour, until 1951, no "ethnic differentiation" was emphasised within the DRMC, even where the African members were in the majority: "Even in the inland provinces (Free State, Transvaal and Natal), where there were more African than coloured members in the DRC Mission churches, coloured and African members belonged to the same congregations and one synod in 
one church" (Saayman 2017, in Plaatjies-Van Huffel and Modise 2017, 120). However, in 1951 the DRC organised its mission work in the Transkei (now part of the Eastern Cape) into a separate church formation - the DRC Bantu Church. Saayman relates this development to practical considerations, e.g. the use of language in worship: "There thus seemed to be centrifugal as well as centripetal forces at work in the various DRC Mission Churches (mainly constituted on a geographical, non-ethnic and non-tribal basis at this stage) in the early 1950s" (Plaatjies-Van Huffel and Modise 2017, 121). The Tomlinson Commission (1955) of the newly consolidating apartheid government, introduced the ethnically charged terminology "Bantu" and argued that African society in South Africa consisted of four distinct cultural entities - the Nguni, the SothoTswana, the Venda, and Shangaan-Tsonga (Plaatjies-Van Huffel and Modise 2017, 122). The distinguishing features of these groups were their culture and language. The Tomlinson Report was substantially initiated due to the requests of the DRC and it had an immediate impact on the mission policy of the DRC. Saayman refers to the interpretation of Van der Walt that the Council of Dutch Reformed Churches perceived identity and collective culture to be formative for revealing the church of Christ: "Indeed, Council considered identity and intimacy based on natural relationship and collective culture to be important determinants in the visible revelation of the Church of Christ" (Saayman 2017, in Plaatjies-Van Huffel and Modise 2017, 123).

In 1966, the Dutch Reformed Church in Africa in the Cape experienced the "sudden" secession of the regional synod of Phororo (Northern Cape). The mission work in the Northern Cape was mostly amongst Tswana speakers and already in 1953, the possibility was voiced that the Tswana-speaking converts be incorporated into the Dutch Reformed Mission Church in the Western Transvaal (also Tswana speaking). Saayman argues that this was the first time that ethnicity became the principle for separation in the DRCA and then under the impact of the Tomlinson Report: "What started out as the practical everyday consequence of an inclination the colonists brought with them from Europe had now evolved into acceptance of the ethnical structuring of church membership as final solution" (Saayman 2017, in Plaatjies-Van Huffel and Modise 2017, 124).

Saayman (2017) concludes that the missiological thinking and practice in AngloAmerican circles of the first half of the twentieth century and its impact on the SA church scene, emphasised administrative and organisational factors. It was only since the mid-1950s that the justification for separate churches became clearly ethnotheological. This conclusion seems to be unduly innocent to this author. The first half of the twentieth century saw the expropriation of black property through the Land Act of 1913, the introduction of the colour bar in occupations and the removal of the limited vote from black people. These developments all pivot on ethnic frameworks generated within the Afrikaner church establishment. It would be strange if these ideas and reasoning were not already present also in the mission field early in the twentieth century. 
The second part of Saayman's (2017) essay is devoted to the decisions on church unity. He unfortunately gives a very condensed version of those developments, ignoring the key decision of 1975 by the DRCA in Worcester for church unification and the 1978 decision of the DRMC synod in Belhar to reject an overarching structure joining the different and separate churches into a kind of ethno-federal structure, an "oorkoepelende Sinode" (Loff 1998, 260). Out of these developments the concept of organic and nonracial church unity emerged.

A contribution of the current moderator of the general synod of URCSA (Prof. Leepo Modise), takes us deeper into the type of unity we envisage while simultaneously recognising the character of and obstacles to this unity (Plaatjies-Van Huffel and Modise 2017, 135-152). Prof. Leepo Modise (in Plaatjies-Van Huffel and Modise 2017) firstly grounds the idea of church unity in the Trinity. For him, the unity of the church is analogical to the "relational, differentiated and fecund" unity of God Triune. However, Modise also approaches the life of the church from the communal perspective of African culture and especially through the image of the family. For him, the social aspect of the African experience predominates over the individualistic aspect. Modise thus finds a configuration of unity with diversity where unity predominates without erasing the factors that make for diversity: "The proclamation of the Confession of Belhar that reconciliation is possible in Christ and that cultural and other 'natural' differences are gifts for the building up of the church and society should be heard loudly and clearly across South Africa and the whole of Africa" (Modise in Plaatjies-Van Huffel and Modise 2017, 139).

The literature that we have drawn on so far indicates an awareness of the reality of diversity. The unfortunate history of South Africa has, however, clouded the creative reflection on this issue. The argument by Saayman, in the previous section, boils down to suspecting a hidden racism in any development to think through the challenges presented by diversities. The approach by Modise builds more explicitly on the insights of the Belhar Confession, and his conceptualisation of both the Trinity and of African experience allows more creative engagement with the issues. Both theologians (Saayman and Modise), however, do not problematise the issues and merely state the current positions on these challenges.

Before I take up the theoretical discussions of diversities and the framework of the Belhar Confession on this thorny challenge, I will first clarify why the issue of diversity has become a very urgent challenge, not only in URCSA, but without doubt also in the global church.

\section{Diversity Returns: Claimed and Obscured}

The theologian, Prof. Simon Maimela, raises the issue of diversity very pertinently in 1996 as part of a collection in honour of Archbishop Desmond Tutu (Maimela 1996, in Hulley, Kretzschmar, and Pato 1996, 80-92). He observes that many black theologians were suspicious of any talk of inculturation. They rather opted for black theologies of 
liberation with the emphasis on socio-economic and political liberation. Black South Africans, however, gradually came to appreciate their African heritage and began to search for resources to reassert their African identity. Maimela relates the survival of black South Africans from the onslaught of colonialism to their preservation of the core of their African identity and culture. He defines this African culture as "that internal force and resilience which has helped Africans ... to survive despite the atrocities of slavery, colonialism and post-colonial brutality, dictatorships and oppression which still characterise most African countries" (Maimela 1996, in Hulley et al. 1996, 82). For Maimela, all culture is a double-edged sword. It lends itself for beneficial and destructive uses. He highlights especially the subordination of women in African cultures to perpetuate the privileged status of men: "Indeed, too often culture has been used and is used by African males in the family context, as husbands, fathers, sons, brothers, etc., to try to safeguard and perpetuate their dominant positions at the expense of females" (Maimela 1996, in Hulley et al. 1996, 83). But Maimela also emphasises that oppressed people often embraced those aspects of their culture or religion that strengthen their cause against class domination. Many African Christians, therefore, resist a type of Christianity that erases all African cultural expression. This same resistance had led to breakaway groups and the formation of African Independent Churches. Maimela identifies in both culture and religion a "dialectic nature" lending it to uses of domination and resistance.

The strength of Prof. Maimela's approach is that he neither absolutises culture and ethnicity, nor does he reduce it to superficial accretions that can be dispensed of easily. It rather belongs to the core of identity and it is simultaneously a contradictory resource in the growth towards greater freedom: "Yet God's gift of racial and cultural diversity should be seen as a source of strength and enrichment. Indeed, life would be dull and poor if different ethnic groups were to be reduced to sameness or one common denominator" (Maimela 1996, in Hulley et al. 1996, 90).

The issue of various diversities has obviously been present in URCSA since its inception. The church was structured mostly along the lines of the South African provinces, except for the synod of Namibia. This meant that many synodical boundaries coincided with cultural and ethnic boundaries, e.g. the KwaZulu-Natal synod is overwhelmingly isiZulu speaking, while the Free State synod is primarily siSotho speaking. The Southern synod of Gauteng is a true tapestry of many diversities of ethnicities and cultures, gender, age, and so forth. There are also synods where a number of cultures and ethnicities have a substantial presence, e.g. Namibia, Phororo (Northern Cape and North West), Cape Synod and Northern Synod. The issues of gender, age and different abilities are crosscutting over all these boundaries and are present in all contexts.

URCSA and her predecessors have focused over many years on the issue of unity. This is quite understandable in light of our apartheid history. However, unity cannot be deepened by marginalising critical constituencies in both church and society, i.e. 
different cultures, women, youth, the disabled and lay people. These issues tend to surface at critical times in the life of the church. In the Cape Synod meeting of 2018, the issue of diversity emerged forcefully (URCSA Acts of Synod 2018, 41-45). When the election of the moderature/executive of the Cape Synod was in progress, an Afrikaans language speaker was elected as moderator and an isiXhosa speaker as deputy/assessor of synod, both male. The next portfolio to be filled was the scribe of synod. A younger Afrikaans-speaking male minister was elected. Then it was the turn to fill the portfolio of judicial office/actuarius of synod. In that case a woman, Prof. Dr Mary-Anne Elizabeth Plaatjies-Van Huffel was elected, also Afrikaans-speaking. Plaatjies-Van Huffel was a lecturer in church polity and ecclesiology at the University of Stellenbosch and past moderator of the general synod of URCSA. She was elected with an overriding majority, but then a stormy debate ensued regarding the representation of isiXhosa speakers in the executive.

Members of synod pointed to a decision at previous synods of the Cape that the executive of synod will consist of equal numbers of Afrikaans and isiXhosa speakers. The Cape Synod had 315 congregations represented, of which 92 were isiXhosa speaking and the rest were Afrikaans speaking. This decision was already made in 2002 and the subsequent elections did not adhere to it strictly, e.g. the 2006 elections did not follow this 50:50 allocation. However, some delegates now insisted that the 50:50 rule had to apply regarding the key executive positions. There were many female delegates at the synod and they questioned why this rule only applied to cultural representation and not to gender. The outcome of this intense debate was that the elected delegate, Plaatjies-Van Huffel, withdrew her candidacy (she effectively resigned) and another male isiXhosa-speaking minister was subsequently elected to the portfolio. A number of delegates to the synod refused to participate in the subsequent election of the actuarius. That meant that all the key portfolios were filled by male pastors. The meeting continued to elect four additional members that included Plaatjies-Van Huffel. The election results left many delegates frustrated, especially women, and it raised the question of whether the church was dealing faithfully with representation in leadership and other structures of the church. This development in the Cape Synod was perhaps a watershed event, reminding the Cape Synod, and possibly the whole of URCSA, that we need to address the diversities within the church in a way that does justice to the many voices and gifts within the church, not least of which women and our various cultural communities. The ways the Cape Synod dealt with its elections were overly rigid and mechanistic. While justly wanting to ensure inclusivity with regard to culture, it marginalised an equally important constituency - women - and it did not pause to reflect both sociologically or theologically on the challenge of diversity.

\section{Diversity Theorised}

There are many voices within the churches and society that strive for greater inclusion. These constituencies form organic parts of the churches, but hidden mechanisms and restrictive ideologies have operated to limit the full participation of these constituencies. 
The situation lends itself to great complexity since multiple diversities intersect and contest the spaces of representation and articulation in all social formations. These include the fundamental divisions of class, culture, gender, ability, age, and expertise. South African history, both in society and in the churches, has given almost overriding prominence to "racial" oppression. This has tended to obscure the very real class divisions within the ranks of the racially oppressed. We have seen in the discussion of the work of Maimela that, even where racial and class exploitation is often addressed, the restrictions on women generated by culture and theology are often continued. The marginalisation of people with different abilities is addressed very slowly despite the fact that the Christian churches and URCSA, in particular, have been pioneers in the empowerment and support of these congregants. At the Cape Synod of 2018, out of about 200 ministers, one minister had impaired hearing. The Cape Synod of URCSA has expanded both the executive and the different ministries to ensure much greater participation of younger ministers and of lay delegates (elders and deacons). Unfortunately, URCSA works with a pragmatic approach and has never considered the issue of diversity in a sustained way. The situation is further complicated by the fact that none of the above categories of diversity is discrete. There are no uniform cultural blocks; no undifferentiated women formation. Lay people do not function as deculturised and declassed representatives. Everyone is embedded in a social context and in a nexus of social relations that often feature all of these dimensions.

\section{The Politics of Difference: Iris Marion Young}

The late political philosopher at the University of Chicago, Prof. Iris Marion Young, presents a penetrating analysis of the different configurations of diversity in her contribution to the W.E.B. Du Bois lectures at Humbolt University in Berlin during 2004/2005 (Young 2007, in Appiah, Benhabib, Young, and Frazer 2007, 79-116).

Young addresses the issue under the title of "Structural Injustice and the Politics of Difference." She identifies at least two versions of the politics of difference. The one version she calls a "politics of positional difference" and the second a "politics of cultural difference." Prof. Young draws attention to the concerns of feminist, anti-racist and gay liberation activists, that the structural inequalities, in which different constituencies are positioned, did not align with the dominant paradigm of equality and inclusion. This paradigm pivots the advancing of justice and equality on the strategy of non-discrimination irrespective of the social position of people: "In this ideal, which many understood as the liberal paradigm, social justice means ignoring gender, racial or sexual differences among people" (Young 2007, in Appiah et al. 2007, 79). This difference-blind approach equates equality with equal treatment and in the process disregards the material differences in "social position, division of labour, socialised capacities, normalised standards and ways of living" that impact on the experience of excluded groups.

The politics of cultural difference, again, intensified in the 1990s. This approach focuses on the difference of nationality, ethnicity and religion. It argues for the importance of 
cultural particularity for people as opposed to a type of individualism that renders culture accidental to the self or voluntarily adopted: "Contrary to arguments for cultural neutrality which until recently have been the orthodox liberal stance, the politics of cultural difference argues that public accommodation to and support of cultural difference is compatible with and even required by just institutions" (Appiah et al. 2007, 80). According to Young, the politics of cultural difference gained impetus with the essay by Charles Taylor on "Multicultural Citizenship and the Politics of Recognition." It was then treated more extensively by Will Kymlicka in his book Multicultural Citizenship. At the heart of both approaches to the politics of difference is the conviction that a commitment to political equality cannot imply endorsing sameness and discounting group difference both in public policy and in the treatment of individuals: "They both argue that where group difference is socially significant for issues of conflict, domination, or advantage, equal respect may not imply treating everyone in the same way" (Young 2007, in Appiah et al. 2007, 81).

Young proceeds to define the politics of positional difference and analyses three instances of such politics, i.e. disability, racial inequality, and gender inequality. She then examines the politics of cultural difference and offers a sympathetic critique of this approach.

\section{The Politics of Positional Difference}

Young (2007) proposes that social groups are located at different positions in society through structural processes that generate status, power and opportunity: "Important axes of structural social privilege and disadvantage concern the social division of labour, hierarchies of decision-making power, practices of sexuality and body aesthetic, and the arrangement of persons in physical and social space" (Young 2007, in Appiah et al. 2007, 83). There are institutional rules, dominant norms, political and economic enticements, and even stereotypical assumptions that generate and reinforce inequalities between groups. These inequalities logically limit opportunities for self-development and access to resources and affect the respect that some groups receive. The structural positioning of social groups does not require that every member of a particular group suffers deprivation. Such groups are generally more vulnerable and have to deal with many obstructions to well-being. The dynamics of positional difference reproduce structural inequalities unless explicit action is taken to address them. Part of this deliberate approach is the overt recognition of social group difference and intervention through compensation, revaluation and empowerment: "Thus to remove unjust inequality it is necessary explicitly to recognise group difference and either compensate for disadvantage, revalue some attributes, positions or actions, or take special steps to meet needs and empower members of disadvantaged groups" (Young 2007, in Appiah et al. 2007, 84). Young sees socio-economic class as paradigmatic of structural location-referring to position in the social division of labour, in decision-making fora and of fashion and taste. 
Young (2007) identifies three forms of group difference besides her paradigmatic example. These groups are all pertinent to the topic of this essay and I will, therefore, proceed to touch on them briefly.

Young faults discussions on social justice for ignoring disability as a politics of positional difference. She argues that physical and/or mental impairment is so widespread that it is wrong to treat it as an uncommon condition: "I suggest that we can learn much about social justice generally as concerning issues of structural inequality, normalisation, and stigmatisation, if we decide to make disability paradigmatic of structural injustice, instead of considering it exceptional" (Young 2007, in Appiah et al. 2007, 85). Young highlights the arguments around "merit" that require levels of excellence and forms of demeanour for people to qualify. This argument at most supports the needs of the "disabled" and counts them unable to make a significant contribution to production. Young concurs, rather, with the disability rights movement that the "lack of fit" between the abilities of some people and the dominant structures, practices and norms in society, is the critical issue. There are hegemonic standards that position some people to be limited in experience and aspiration: "Many people with disabilities unfairly suffer limitation to their opportunities for developing capacities, earning a living through satisfying work, having a rewarding social life, and living as autonomous adults" (Young 2007, in Appiah et al. 2007, 87). The crux of the matter is that an approach that is blind to difference cannot respond adequately to this structural positioning. Young proposes an inspiring intervention that starts by noticing the differences and ceasing to regard the disabled as deviating from the norm, but rather to accommodate their specific capacities.

The second example of positional difference that Young addresses is the issue of racial inequality. She defines racism as the structural processes that identify a particular body aesthetic as the normal, determining that certain undesirable forms of work are appropriate for certain groups, enabling the continuing segregation of racialised groups and labelling the habitual behaviour patterns of these segregated groups to be aberrant. Young's definition encapsulates cultural, spatial, economic and behavioural elements. She further contends that racial categorisation employs a black/white dichotomy organised hierarchically. It also generates stigmatisation of body types. Young observes that these racialised processes are globally at work, including in the USA and Europe: "A similar process of racialisation has occurred in Europe, which positions persons of Turkish, North African, South Asian, sub-Saharan African, and Middle Eastern origin as Other, and tends to restrict them to lower status positions in the social division of labour" (Young 2007, in Appiah et al. 2007, 90).

Young makes a third example of the politics of difference by analysing the generation of gender inequality. She notes how the political struggle for women's rights often endeavours to have women recognised as the "same" as men with respect to autonomy. Feminist politics of positional difference rather requires that the structural processes that position women and men differently, be recognised: "On this account, gender injustice 
also involves processes of structuring the social division of labour and the fit or lack of fit of bodies and modes of life with hegemonic norms" (Young 2007, in Appiah et al. 2007, 92). Young characterises this lack of fit between women's experience and social structure as follows: "Basic structures of gender comportment, assumptions that the normal body is implicitly male, the structures of heterosexual expectations, and the sexual division of labour nevertheless continue structurally to afford men more privilege and opportunity for access to resources, positions of power and authority, or the ability to pursue their own life plans" (Young 2007, in Appiah et al. 2007, 92). Young proposes at least three issues to be addressed: public institutions must accommodate the bodily specificity of women, enabling them to be women and excel in those institutions; the presence of womanliness, including their sexuality must be acknowledged without requiring of women to present themselves like men; the social division of labour that burdens women with most of the unpaid care work and domestic responsibilities, needs to change.

The issues that were highlighted so far all relate to the structural position of certain groups in society. These positions of difference cannot be reduced to cultural traditions and frameworks. However, there is a politics of cultural difference that has different roots and expression than a politics of positional difference.

\section{The Politics of Cultural Difference}

Young distinguishes what she calls structural social groups, i.e. groups based on their positioning on axes of privilege and disadvantage, from groups defined by "societal culture." Young engages the definition of these cultural groups by the theorist Will Kymlicka. She argues that: "The societal culture to which a person relates is an important aspect of his or her personal identity; his or her personal autonomy depends in part on being able to engage in specific cultural practices with others who identify with one another as in the same cultural group; one being able to speak the language one finds most comfortable in the conduct of everyday affairs; on having the space and time to celebrate group specific holidays and to display symbols important to the group" (Young 2007, in Appiah et al. 2007, 96, 97). According to Young, Kymlicka observes that most societies today are constituted by at least two cultural groups and often even more. Young identifies the key issue raised by cultural difference to be the necessity to mutually accommodate the practices and cultural expressions of one another and the public recognition of diversities.

The politics of cultural difference works with the assumption that the state or the polity is dominated by one or other of the constituting groups, usually the majority group. Political conflict arises when the dominant group limits the ability of one or more cultural minorities to give expression to their particular forms. Sometimes the pervasiveness of the dominant culture threatens to marginalise the minority culture to the point of extinction. Members of such threatened cultural groups then demand special rights to encourage the flourishing of their culture, or they urge either a polity of their own or a federated relationship to the dominant cultural group. 
Kymlicka identifies ethnic groups and national groups to be the two types of cultural groups that constitute today's multicultural politics. In the light of Kymlicka's multicultural analysis, Young probes the implications of "a recognition" of cultural groups: "Since cultural minorities often suffer political disadvantage in getting members elected to office and in voicing their interests and perspectives in representative bodies, does justice call for installing forms of group representation?" (Young 2007, in Appiah et al. 2007, 98). Other theorists have built on the discussion of Kymlicka and have included religion alongside ethnicity and nationality as principal forms of "deep diversity." For Young, the logic of religious adherence differs from other forms in that religious doctrine and ceremony both contribute to identity and are felt to be mandatory.

Kymlicka's framework of multiculturalism has been criticised on at least two important points. He seems to operate with an excessively homogenous concept of societal culture, whereby ethnic and other groups have a singular and uniform understanding of themselves. Others argue that he essentialises cultural difference, approaching culture as coherent wholes and fully detached from other cultures. The theorist, Seyla Benhabib, takes a more measured approach. She recognises the distinct cultures but locates them in a dialogic relationship: "On the dialogic view, members of different cultural groups within a society often influence one another and engage in productive cultural exchange, and this interaction ought to be mobilised to resolve intercultural conflict" (Benhabib 2007, in Appiah et al. 2007, 100). Young identifies two crucial similarities between a politics of positional difference and a politics of cultural difference. Both approaches sit uneasily with the possibility that some groups will dominate public meaning and opportunity. Both also challenge the difference-blind principle in public policy. These approaches emphasise that justice sometimes necessitates recognising social and cultural difference, consequently treating people differently. Young opts to encourage both forms of politics, since in her view the "oppression" of minority cultures often fuses with structural inequalities and thereby limits the opportunities of particular groups.

Young expresses a number of reservations with regard to the politics of cultural difference, nonetheless. She argues that such an approach does not account for the structural inequality generated by racism and gender discrimination. She also criticises the approach for focusing primarily on state action, to the neglect of civil society efforts. Young intends to stake a claim for different forms of the politics of difference. Her recommendations with regard to concrete steps are, therefore, limited. Moreover, she writes from the United States context where a number of minorities experience real exclusion and domination.

Young's insights need to be contextualised for the South African and civil society context of the church. In South Africa, racial dominance has generated a highly stratified society in which white people, including white women, have enjoyed tremendous advantages. Even in regard to disability, the white racialised structure has advanced the interests of white citizens. On the other hand, it is evident that black communities are 
similarly stratified so that black women are often deprived of vital opportunities and resources. Even under conditions of apartheid oppression, black men tended to enjoy relative advantages vis-à-vis black women, and these differentiated patterns of opportunity have persisted under the post-apartheid democratic dispensation.

\section{Diversity Theologically Assessed}

The Belhar Confession of 1986 emerged from theological reflections among Reformed Christians in South Africa within a variety of contexts. Plaatjies-Van Huffel traced the genesis of the Confession and situated it within its historical and theological context (Plaatjies-Van Huffel 2014, 301-324). The Belhar Confession came as a theological response of mostly black Christians to the conditions created by apartheid and segregation. It is a mark of the Confession, however, that key white theologians and ministers contributed to its conceptualisation. The Confession is, therefore, not tied to a "racial" origin and the community it envisages is principally antiracist.

However, the Belhar Confession is a theological response to a particular socio-historical formation (apartheid) that received its legitimisation from a pseudo-theological ideology, generated within the white Reformed tradition in South Africa. This Confession was formulated to expose the heretical character of the apartheid theology and it addressed the apartheid claims of racial incompatibility and "separate but equal" development, while simultaneously reinterpreting the reality of multiple diversities in church and in society.

Prof. E. van den Borght, (Desmond Tutu chair at the VU) locates the challenges of sociocultural identities to the unity of the churches worldwide, to a possible vulnerability in Christian ecclesiology: "Not only South African churches, but churches worldwide struggle with the question of how to recognise sociocultural identities - such as national, ethnic, and tribal identity - while at the same time confirming the unity of the church" (Van den Borght 2012, 2). Van den Borght himself comes from a church that adopted the Belhar Confession and experiences the tensions between the Dutchspeaking and the French-speaking members in Belgium.

He investigated whether the Belhar Confession addressed the relation of unity and socio-cultural identities adequately. He recognises three elements in the Confession that assist with this ecclesiological challenge. The Belhar Confession emphasises the central place of the unity of the church; it secondly employs a reconciliation and justice "rationale," and the third element is the confessional status of the document. Van den Borght questions whether the Belhar Confession was adopted in various churches for the above reasons. He thinks that ecumenical partners have adopted the Belhar Confession, not for its ecclesiological insights but on the basis of their own justice concerns: "To conclude this section, I doubt whether challenges in denominations regarding socio-cultural identities have been decisive in discussions regarding the adoption of the Belhar Confession" (Van den Borght 2012, 4). Van den Borght also concludes that there are "major" elements in the Confession that militate against an 
adequate treatment of socio-cultural identities. He identifies "the lack of room it allowed for socio-cultural diversity within the unity" (Van den Borght 2012, 12), despite the general references to diversity. He summarises the position of Belhar to be that "[T]he diversity is part of the unity of the church and the aspects of the diversity cannot be claimed as elements determining membership of a church" (Van den Borght 2012, 12). This summary seems, to me, to be a correct reading of the Belhar Confession. However, Van den Borght wants to go further. He asks how "creational diversity" is incorporated into ecclesiology where unity of the church is confessed. Van den Borght seems to think that the ecclesiology of the churches, as it relates to diversity, is hopelessly undertheorised and he fears that because of this lacuna, the concept of unity and of diversity can be abused.

Prof. Dirk Smit was the principal formulator of the draft Belhar Confession of 1982. He reflected in a lecture on the theological content of the Belhar Confession and proceeded by analysing the principle sections of the Confession to draw out its theological import (Smit 2012, 184-202). Smit observes that behind the introduction to the Confession lies the question regarding the true fields of force that determine the life of the church-its loyalty to its confessional tradition or its attachment to volksgroep ("national group") and cultural heritage. The issues of the impact of nationalist striving and cultural Protestantism on the shape of the church lurked behind the formulation. The third thesis of the Theological Declaration of Barmen about the belonging of the church, both in proclamation and polity to Jesus Christ, also informed the formulation of the Belhar Confession.

Smit argues that the framework of Christian freedom and Christian responsibility structured the Confession and situated the three themes of unity, reconciliation and justice: "Binne dié teologiese raamwerk, wat 'n mens dalk oortuigings aangaande ware Christelike vryheid [die aanhef] en ware Christelike verantwoordelikheid [die slot] kon noem, alhoewel die terme nie self gebruik word nie, kom die drie temas van eenheid, versoening en geregtigheid dus ter sprake" (Smit 2012, 190). ${ }^{1}$

After his initial comments, Smit then proceeds to reflect on the different central clauses. Regarding "unity" he highlights three aspects and observes firstly, that the church confesses that it is already one and united-i.e. it confesses the unity as a gift and not as a human creation. Three characteristics define this unity: people are called from the entire human race to become a holy community; this unity is constituted through the reconciling work of Christ and effected by the binding power of the Holy Spirit.

The second aspect regarding the "spiritual" unity that has in effect already been created, is that the church is charged to embody this unity visibly in service of advancing the Gospel and to the praise of God. The Confession declares that all powers that obstruct

1 [Own translation] Within this theological framework, which could be called convictions concerning true Christian freedom [in the introduction] and true Christian responsibility [the conclusion], although the terms itself are not used, the three themes of unity, reconciliation and justice are raised. 
this visible unity, whether division, enmity or hatred, have already been overcome by Christ.

The third aspect of unity relates to its contents. It includes the rich and wonderful diversity of communities that can only be formed in freedom: "Die sigbare eenheid sluit 'n ryke en wonderbare verskeidenheid in, nie uit nie - dis die eerste punt. Die sigbare eenheid kan slegs in vryheid gestalte kry, en nie afgedwing word nie-dis die tweede punt" (Smit 2012, 191). ${ }^{2}$

Smit recalls that the issue of diversity was highly contentious, precisely because of the ideology of separation on the basis of "racial" diversity. Nonetheless, the Confession declares various diversities to be opportunities for service and enrichment within the one visible church. Smit adds a third point, namely that neither freedom nor diversity be allowed to undermine the visible unity. He summarises the unity as follows: "Die eenheid is nóg uniformiteit, nóg bloot struktureel en organisatories. Die liggaam leef juis van verskeidenheid en onderlinge en wedersydse diens, in die plaaslike gemeente en in die kerkverband" (Smit 2012, 192). ${ }^{3}$

With regard to the clause on reconciliation, Smit only emphasises that this reconciliation in Christ overrides the natural and cultural differences between believers. He again insists that the Christ-realised reconciliation be exercised and embodied in history.

Addressing the clause on justice, Smit points out that the church speaks in doxological terms about the character of God. The question arose in the synod of 1982, whether a more direct liberation language that "God is the God of the poor," would not be more appropriate. This was rejected on the basis that the church does not believe that God inserts Himself in a purported class war on the side of the poor and against others. What God indeed chooses is to stand with the poor and oppressed and to reject all forms of injustice, while opposing the powerful that abuse their power. In this the church is called to follow God. The church is, furthermore, called to discern and judge the fitting time and circumstances to witness against and resist injustice.

Smit concludes his lecture by relating the themes of the Belhar Confession to the broader ecumenical debate. He observes that the motive of "reconciled diversity," a unity-indiversity approach presents perhaps too little substance. The existing divisions are merely justified by such an approach. He then raises the issue of the possible impact if the diversity-in-unity of the Belhar Confession were practically exercised: "Maar wat sou Belhar se verskeidenheid-in-eenheid konkreet kon beteken, hoe sou dit prakties

2 [Own translation] The visible unity includes, not excludes, an amazing diversity - this is the first point. The visible unity can only be embodied in freedom and not be forced through - this is the second point.

3 [Own translation] The unity is neither uniformity, nor merely structural and organisational. The body subsists of diversity and underlying and mutual service, in the local congregation and in the denomination. 
beliggaam en beoefen kon word, in die orde en in die lewe van die Protestantse kerke?" (Smit 2012, 196). ${ }^{4}$

Smit finally raises the concern of the true meaning of reconciliation in contexts of radical multiculturalism and severe race divisions. He concludes that the confessing of unity, reconciliation and justice in their close relationship entails the true theological content of the Confession.

\section{Conclusion: The Claims of Diversity}

Our investigation into both secular literature and theological resources has shown that the issue of diversity, whether in society or in the church, is an urgent matter. The challenges that diversity poses are not new ones. Since all societies have been constituted by multiple cultural groups and/or structural group formations, they have had to deal with the demands these presented. Within the Christian churches, diversity has been - from the beginning - a definite feature, challenging the churches to express in their institutional and community patterns the vision of the Christian church as the Body of Christ. However, due to the vagaries of historical development, the churches and societies have responded in various ways to the claims of diversity. Some societies and churches have under-emphasised the challenge, usually to maintain a dominant hegemony of one culture or one dominant political group. Others have wrestled with the issue and created the conditions for a much greater flourishing of the gifts and contributions of everyone, including diverse groups.

The South African political order has created hierarchies of dominance for centuriesfirst under colonialism and then under apartheid. For this essay the focus has been on the period since the Reformed Church tradition was constituted on South African soil. It has been shown that the segregated order encouraged by the white Reformed churches in South Africa, used and interpreted diversity to subjugate black Christians and black people generally, and to extend their white dominance by employing culture, but also gender, as part of their politico-missiological project. If the colonial and apartheid church establishment distorted the character of both the unity and the diversity of the churches, what then constitutes an enriching diversity in the context of meaningful church unity?

Iris Marion Young has argued that the diversity of society and of civil structures are expressed in two forms - difference of position, relating to structural groups in society like women, the disabled and racial exclusion among others; and cultural difference. She concludes that a difference-blind approach, ostensibly employing criteria of merit, cannot do justice to the ways that groups and people are located in the configuration of society to the critical detriment of many. The people that normally argue for a difference-blind approach are generally the majorities that exercise a hegemony which

4 [Own translation ] But what could be the meaning of the diversity-within-unity of Belhar concretely, how can it be practically embodied and practised, in the order and in the life of the Protestant churches? 
reinforces their access to power, decision making authority and their control of normative frameworks. Young calls for explicit recognition of differences and intervention through compensation, revaluation and empowerment.

The Uniting Reformed Church in Southern Africa has adopted the Belhar Confession as a confessional standard that directly and explicitly addresses both unity and diversity. The church has been struggling, however, to give effect to its own confession since it emerged from a context where the quest for unity was overriding. The Belhar Confession incorporates clearly both concerns raised by Young. It deals with cultural diversity, but it also addresses structural diversity, focusing particularly sharp criticism at the unjust and oppressive ways in which the South African polity and the theological justification of apartheid have generated conditions of suffering, poverty, hunger and oppression. The call within the Cape Synod of URCSA for greater cultural representation within the church cannot be faulted. Where Young addresses mainly cultural diversities external to a dominant culture, URCSA must deal with cultural diversity internal to the church.

This call of some members within the Cape Synod, however, worked from a default position, i.e. it assumed that cultural inclusion refers to male inclusion. The requirement of cultural inclusion must be problematised and situated within the context of other equally important voices, in particular of women, of laity and of the disabled, to have their concerns addressed adequately. These insistent voices do not pose a threat to the fundamental unity created by Christ on which the house of URCSA is rising. But by marginalising these voices, the unity becomes hollow and the resources of people that make for a richer community are neglected. Young also raises the issues of representation and empowerment. Such representation, to be meaningful, cannot be merely symbolic. It has to incorporate a substantial presence and a redefinition of normativity to impact meaningfully on the inherited ways of faith community and leadership. The Belhar Confession understands the unity as infusing the life of the church and the diversities as forms of enrichment that must always be defined within the unity.

\section{Biographical Note}

The author is a minister of religion in the Uniting Reformed Church in Southern Africa and past moderator of the Cape Regional Synod.

\section{References}

Appiah, K. A., S. Benhabib, I. M. Young, and N. Frazer. 2007. Justice, Governance, Cosmopolitanism, and the Politics of Difference: Reconfigurations in a Transnational World. Berlin: Humbolt University.

Bosch, D. 1983. "Nothing but a Heresy.” In Apartheid Is a Heresy, edited by J. W. De Gruchy and C. Villa-Vicencio, 24-38. Cape Town: David Philip. 
De Gruchy, J. W., and C. Villa-Vicencio. 1983. Apartheid Is a Heresy. Cape Town: David Philip.

Elphick, R., and R. Davenport. 1997. Christianity in South Africa: A Political, Social and Cultural History. Cape Town: David Philip.

Hulley, L., L. Kretzschmar, and L. Pato. 1996. Archbishop Tutu: Prophetic Witness in South Africa. Cape Town: Human and Rousseau.

Kinghorn, J. 1997. "Modernization and Apartheid: The Afrikaner Churches." In Christianity in South Africa: A Political, Social and Cultural History, edited by R. Elphick and R. Davenport, 135-154. Cape Town: David Philip.

Loff, C. J. A. 1998. "Bevryding tot Eenwording: Die Nederduitse Gereformeerde Sendingkerk in Suid-Afrika 1881-1994.” PhD thesis, Protestant University of Kampen.

Maimela, S. S. 1996. "Culture and Ethnic Identity as Sources of Curse and Blessing in the Promotion of Democratic Change." In Archbishop Tutu: Prophetic Witness in South Africa, edited by L. Hulley, L. Kretzschmar, and L. Pato, 80-92. Cape Town: Human and Rousseau.

Modise, L. 2017. "The Unification Process in the Dutch Reformed Church Family and the Uniting Reformed Church in Southern Africa: The Confessional Basis and Confession of Belhar." In Belhar Confession: The Embracing Confession of Faith for Church and Society, edited by Mary-Anne E. Plaatjies-Van Huffel and L. Modise, 135-152. Stellenbosch: African Sun Media. https://doi.org/10.17159/2412-4265/2016/388.

Plaatjies -Van Huffel, Mary-Anne E. 2014. "The Belhar Confession in its Historical Context." Nederduits Gereformeerde Teologiese Tydskrif 55 (1): 301-324. http://ngtt.co.za. https://doi.org/10.5952/55-1-2-527.

Plaatjies-Van Huffel, Mary-Anne E., and L. Modise. 2017. Belhar Confession: The Embracing Confession of Faith for Church and Society, 135-152. Stellenbosch: African Sun Media. https://doi.org/10.17159/2412-4265/2016/388.

Randall, P. (ed.). 1972. Apartheid and the Church: Report of the Church Commission of the Study Project on Christianity in Apartheid Society, Johannesburg: South African Council of Churches and the Christian Institute of Southern Africa.

Smit, D. J. 2012. "Oor die Teologiese Inhoud van die Belydenis van Belhar.” Acta Theologica 32 (2): 184-202. https://doi.org/10.4314/actat.v32i2.11.

Saayman, W. 2017. "Unity and Diversity: An Overview of the URCSA Decisions on Church Unity since 1994." In Belhar Confession: The Embracing Confession of Faith for Church and Society, edited by Mary-Anne E. Plaatjies-Van Huffel and L. Modise, 119-130. Stellenbosch: African Sun Media.

Uniting Reformed Church in Southern Africa. Cape Synod, Acts of Synod, 2018. 
Van den Borght, E. 2012. "Belhar Revisited: The Unity of the Church and Socio-cultural Identities within the Reformed Tradition." Nederduits Gereformeerde Teologiese Tydskrif 53: Supplementum 2, http://ngtt.journals.ac.za. https://doi.org/10.5952/53-0-197.

Villa-Vicencio, C. 1983. “An All-Pervading Heresy.” In Apartheid is a Heresy, edited by J. W. De Gruchy and C. Villa-Vicencio, 59 - 74. Cape Town: David Philip.

Young, I. M. 2007. "Structural Injustice and the Politics of Difference." In Justice, Governance, Cosmopolitanism, and the Politics of Difference: Reconfigurations in a Transnational World, edited by K. A. Appiah, S. Benhabib, I. M. Young, and N. Frazer, 79-116. Berlin: Humbolt University. 